\title{
Blood Transfusion: Prevalence, Indications and Associated Factors in Children Presenting to a Tertiary Health Institution in Southeast Nigeria
}

\author{
Chukwuemeka Ngozi Onyearugha ${ }^{1}$, Nneka Chioma Okoronkwo ${ }^{1,}$, , Prince Ezenwa Onyemachi ${ }^{2}$ \\ ${ }^{1}$ Department of Paediatrics, Abia State University Teaching Hospital, Aba, Nigeria \\ ${ }^{2}$ Department of Community Medicine, Abia State University Teaching Hospital, Aba, Nigeria
}

Email address:

chukwuemekaonye@yahoo.com (C. N. Onyearugha), nnekaceo@rocketmail.com (N. C. Okoronkwo),

ijeclinic@gmail.com (P. E. Onyemachi)

${ }^{*}$ Corresponding author

\section{To cite this article:}

Chukwuemeka Ngozi Onyearugha, Nneka Chioma Okoronkwo, Prince Ezenwa Onyemachi. Blood Transfusion: Prevalence, Indications and Associated Factors in Children Presenting to a Tertiary Health Institution in Southeast Nigeria. American Journal of Pediatrics.

Vol. 7, No. 2, 2021, pp. 53-56. doi: 10.11648/j.ajp.20210702.13

Received: March 15, 2021; Accepted: April 6, 2021; Published: April 13, 2021

\begin{abstract}
Blood is an essential component of paediatric care worldwide. Blood and blood products are scarce and expensive and may be associated with health hazards post-transfusion. This study aims at determining the prevalence, indications and associated factors of blood transfusion in children in an academic hospital. Materials and Methods: This was a retrospectively review of all records of blood transfusions conducted at the Children's Emergency and Paediatrics wards of the State University Teaching Hospital, Southeast Nigeria; from $1^{\text {st }}$ January 2016 to $31^{\text {st }}$ December 2017. Results: The prevalence of blood transfusion was $7 \%$. Total number of transfusions was 56. Male: female ratio was 0.8 : 1 . Median age of transfused children was 5 years (range 2 months to 12 years). Forty one (73.3\%) of the transfused children were aged $<3$ years with 17 (30.4\%) being less than 1 year. The most frequent indications for transfusion were severe malaria $36(64.3 \%)$ and sepsis 12 (21.4\%). Sedimented red blood cells, 50 (89.3\%), was the most frequently transfused blood product while whole blood constituted $11.7 \%$. Case fatality among the transfused children was $16 \%$. Discussion: Blood transfusion rate of $7 \%$ is higher than most previous studies, with the most frequent indication being severe malaria. Sedimented red blood cells was the most frequently transfused blood product. Application of malaria control measures is still needed.
\end{abstract}

Keywords: Blood Transfusion, Prevalence, Indications, Southeast Nigeria

\section{Introduction}

Blood transfusion is a significant component of paediatric care $[1,2]$ more so in developing countries where child mortality remains quite high from infectious diseases and malnutrition [3]. Appropriate blood and blood products remain insufficient in healthcare facilities and often unavailable for use when needed in most developing countries [4]. For instance, in Nigeria about half a million units of blood are supplied from blood banks annually where as the country's need is estimated at one and half million units per anum [5].

Often, parents of children in need of blood transfusion in developing countries cannot afford the cost, and may not be eligible or have eligible persons to donate $[4,6]$. Therefore, many of these children who need transfusion do not get it and often die as a result.

Blood transfusion requirements and indications vary from country to country and from region to region in the same country. For instance, whereas the annual transfusion requirements in the United States exceed 15 million units [7], it is estimated at 1.5 million for Nigeria [5]. Also, sickle cell anaemia is noted to be a leading indication for blood transfusion in Jos [8], north central Nigeria; while severe malaria is the greatest indication in Ijebu-ode, Ogun state, southwest Nigeria [9].

Determining the prevalence, indications for blood transfusion and associated factors helps to highlight the 
magnitude of the need of this scarce commodity. It also assists in determining measures of prevention of the disease conditions necessitating its use, thereby bringing the need to barest minimum.

To the best of knowledge of the authors, such an evaluation has not been conducted in our hospital, hence the essence of this study. The results obtained can also be used to determine the provision of blood in the prioritization of treatment needs of the department and also contribute to the formation of a baseline data for future reference.

\section{Patients and Method}

This study was carried out from $1^{\text {st }}$ January 2016 to $31^{\text {st }}$ December 2017. It was a retrospective review of medical records carried out in the Children Emergency Room (CHER) and the Paediatrics Medical Ward (PMW) of the State University Teaching Hospital. The file numbers of the case notes of all children aged 1 month to 16 years, who were transfused within the study period, were noted on the ward registers. These case files were then retrieved from the Medical Records Department.

Relevant information including age, gender, diagnosis, type of blood transfused, duration and outcome of admission was extracted, and documented on excel sheet.

Excluded from the study were children aged $<1$ month or $>$ 16 years, transfusions for surgical and other non-medical procedures, and those whose data were inadequate. Ethical clearance was obtained from the Ethics Committee of the hospital prior to the commencement of the study.

Data were analyzed using SPSS version 22. Results were expressed in prose and frequency tables. Statistical significance was set at $\mathrm{p}$-value $\leq 0.05$.

\section{Result}

The total admissions in CHER and PMW over the study period was 880 . Patients with diagnoses associated with severe anaemia, and requiring transfusion were 62 . This gave a transfusion prevalence rate of $7.0 \%$. Six of the cases were discarded for inadequacy of data. Fifty six were, therefore, used for subsequent analysis. There were 25 males and 31 females giving a male: female ratio of $0.8: 1$. The median age of the patients was 5 years (range $=2$ months to 12 years).

Vast majority, $41(73.3 \%)$, of the transfusion were in children aged less than 3 years, with the greatest proportion, $17(30.4 \%)$, done on patients less than 1 year.

There were 17,14 , and 10 patients in age groups $<1$ year, 1 to less than 2 years and 2 to less than 3 years respectively. This is shown in Table 1.

Among the 17 patients aged less than 1year that were transfused, 15 were males and 2 were females (Table 2). Then, among the 14 aged 1 to less than 2 years, 4 were males and 10 were females. There was no significant difference in gender among the aforementioned age groups $(\mathrm{p}=0.751)$.

There were 10 patients aged 2 to less than 3 years $(2$ males and 8 females) with no significant difference in gender between them and those patients aged less than 1 year. $(\mathrm{p}=0.493)$

Vast majority $36(64.3 \%)$ of the patients were transfused for severe malaria while sepsis $12(21.4 \%)$ was the second most frequent diagnosis for which blood transfusion was done. Table 4.

Many, $50(89.3 \%)$, of the transfusions was sedimented cells while $6(11.7 \%)$ were whole blood.

The mean duration of admission was 6.8 days (Range $=2$ to 17 days). Nine (16\%) of the transfused patients suffered mortality, while 47 (84\%) survived.

Table 1. Gender and age group distribution among patients $<3$ years who were transfused.

\begin{tabular}{llll}
\hline Age group (Years) & Male (\%) & Female (\%) & No (\%) \\
\hline$<1$ & $15(26.8)$ & $2(3.8)$ & $17(30.4)$ \\
$1-<2$ & $4(7.1)$ & $10(17.9)$ & $14(25)$ \\
$2-<3$ & $2(3.8)$ & $8(14.3)$ & $10(17.9)$ \\
\hline
\end{tabular}

Table 2. Relative distribution of gender in the age groups $<1$ year and $1-<2$ years.

\begin{tabular}{llll}
\hline Age group (years) & Number (\%) & Male (\%) & Female (\%) \\
\hline$<1$ & $17(30.4)$ & $15(26.8)$ & $2(3.6)$ \\
$<2$ & $14(25)$ & $4(7.1)$ & $10(17.9)$ \\
\hline
\end{tabular}

$\mathrm{p}=0.751$

Table 3. Relative distribution of gender in the age groups $<1$ year and $2-<3$ years.

\begin{tabular}{llll}
\hline Age group (years) & Number (\%) & Male (\%) & Female (\%) \\
\hline$<1$ & $17(30.4)$ & $15(26.8)$ & $2(3.6)$ \\
$-<3$ & $10(17)$. & $2(3.6)$ & $8(14.3)$ \\
\hline
\end{tabular}

$\mathrm{P}=0.493$

Table 4. Indications for transfusion in the patients.

\begin{tabular}{lll}
\hline Indication & Number & \% \\
\hline Severe malaria & 36 & 64.3 \\
Sepsis & 12 & 21.4 \\
Acute lymphoblastic Leukaemia & 3 & 5.4 \\
Sickle cell disease & 3 & 5.4 \\
Uraemic encephalopathy & 2 & 3.5 \\
\hline
\end{tabular}

\section{Discussion}

Our result showed a prevalence rate of $7 \%$ for blood transfusion. This is higher than the recent transfusion rate of $\leq 4 \%$ reported in Kenya [10] but lower than the $12.4 \%$ reported in Brazil [11]. This recent report from Kenya was lower probably because the value was obtained after applying intensive measures of malaria prevention to stem the high transmission rate of malaria in the region. An earlier study done at Kenya had revealed that severe malaria was by far the most frequent indication for transfusion among their paediatric admissions. Subsequent malaria prevention strategies before the recent study [10] may have brought down the malaria prevalence and also the prevalence rate of transfusion from $>12 \%$ to $<4 \%$ [10].

The report from our study was lower than that of Brazil probably because the Brazilian study [11] was on blood 
transfusion given to both medical and surgical patients. In contrast, our study was derived from blood transfusion on paediatric medical admissions only, hence the lower prevalence rate.

Overwhelming majority, $73.3 \%$, of transfusions in our study were done on children less than three years. This bears similarity to reports in previous studies which documented that significantly more children aged below 5 years were transfused [9, 12]. This could be explained by the fact that under-5 children are more susceptible to diseases capable of manifesting with severe anaemia, requiring transfusion, such as severe malaria, infections and malnutrition [13-15]. This leads to their receiving more frequent transfusions than older children.

Many of the transfusions done in this study were for severe malaria. This is similar to the reports from Ogun State [9], southwest Nigeria and Ghana [16] but contrasts with the result from Jos, North central Nigeria, where sickle cell disease was the most frequent indication for transfusion [8]. Severe malaria being the greatest indication for transfusion noted in our study and that of Ogun State could be explained by the fact that Nigeria is located in high frequency transmission zone of malaria parasites with high humidity, high rainfall, and optimal temperature [17-19]. Similar report from Ghana could be because many places in her urban area also have conducive breeding conditions for the female anopheles mosquito [20], the vector of malaria parasites.

Again, malaria in children aged below 5 years, in whom most of the transfusions were done in these studies often manifests with severe anaemia [21] necessitating transfusion. Severe malaria was not a major indication for transfusion in the Jos study [8] probably because malaria had its highest prevalence among children aged 6 years and above and did not commonly manifest as severe disease with severe anaemia necessitating transfusion [22].

Most of the transfusions in our study comprised sedimented cells. This is similar to the documentation in Ogun State, southwest Nigeria [9], but in contrast with the result in sokoto [23], north west Nigeria, and Oman, Middle East [24] where packed cells was most commonly transfused for severe anaemia due to severe malaria and thalasaemia major respectively [24].

The frequent transfusion of sedimented cells in our study and in the Ogun State study could be explained by the diagnosis of severe malaria as the most frequent indication for blood transfusion. Also, sedimented cells are readily available. In contrast, packed red cell (PRC) transfusion was the most frequent transfusion in Sokoto and Oman because the most frequent indication of transfusion in these places was thalassaemia major, for which PRC was also appropriate and also readily available in their setting.

Our study revealed that $16 \%$ of the patients transfused suffered mortality. This value is higher than $12 \%$ mortality reported in a study done at 10 county hospitals in Kenya [25] and $6.2 \%$ reported in a study in Benin City, South-South Nigeria [26]. However, it is lower than $21.5 \%$ mortality reported at Ogun State [9]. Mortality rate recorded in transfused children could be caused by factors such as comorbidities in transfused patients, late presentation of cases to health care facilities, as well as inadequacies in the transfusion administering process on the part of care givers and the health facility. The later depends on the willingness of caregivers to give consent for transfusion, state of readiness, adequacy and affordability of services of the health facility. This underlines the essence of governmental support for provision of essential healthcare in resource poor settings of developing countries.

\section{Conclusion}

The transfusion rate in our study is high. Vast majority of the recipients were children aged less than 3 years. Severe malaria was the most frequent indication for blood transfusion. Mortality rate was $16 \%$. Application of malaria control measures (use of insecticide treated bed net, residual indoor spraying of insecticides) and early diagnosis/treatment of malaria, particularly in children under 3 years would go a long way in stemming the high prevalence of malaria and blood transfusion rate.

\section{Authorship Contributions}

$\mathrm{O} \mathrm{C} \mathrm{N}$ conceived and designed the manuscript, helped in acquisition of data, analysis and interpretation of data, and also wrote the manuscript.

$\mathrm{O} \mathrm{N}$ C contributed in the design and revision of the manuscript and gave final approval of the version to be published.

O P E N helped with acquisition of data and interpretation of the analyzed data, edited the manuscript and gave final approval of the version to be published.

\section{Conflict of Interest}

The authors declare that they have no competing interests.

\section{Acknowledgements}

Our gratitude goes to the nursing staff at Children Emergency Room and Paediatrics Ward, for extracting the folder numbers of patients from the admission registers, and the Medical Records staff for retrieving the case files.

\section{References}

[1] Jindal G, Guglani V, Gupta V K, Kaur R. Appropriateness of Blood component transfusion in children in a tertiary care teaching hospital. Pediatr Oncall J. 2015; 12: 69-75. doi: 10.7199/ped.oncall.2015.52.

[2] Bharadwaj A, Khandelwal M, Bhargava SK. Perioperative neonatal and paediatric blood transfusion. Indian J Anaesth. 2014; 58 (5): 652-657. doi: 10.4103/0019-5049.144679. 
[3] Brabin BJ, Coulter JBS. Nutrition-associated disease. In: Cook GC, Zumla AI, editors. Manson's tropical diseases. London: Saunders; 2003. pp. 561-80.

[4] Custer B, Zou S, Glynn SA, Makani J, Tayou Tagny C, El Ekiaby $\mathrm{M}$ et al.. Addressing gaps in international blood availability and transfusion safety in low- and middle-income countries: a NHLBI workshop. Transfusion. 2018; 58 (5): 1307-1317. doi: 10.1111/trf.14598.

[5] Aneke JC, Okocha CE. Blood transfusion safety; current status and challenges in Nigeria. Asian J Transfus Sci. 2017; 11: $1-6$.

[6] Towards 100\% Voluntary Blood Donation: A Global Framework for Action. Geneva: World Health Organization; 2010.

https://www.who.int/bloodsafety/publications/9789241599696 /en/.

[7] Lotterman S, Sharma S. Blood Transfusion. [Updated 2020 Jul 31]. In: StatPearls [Internet]. Treasure Island (FL): StatPearls Publishing; 2020 Jan-. Available from: https://www.ncbi.nlm.nih.gov/books/NBK499824/.

[8] Okpe ES, Abok II, Diala UM, Okolo SN, Joseph DE. Indications for Blood Transfusion among Children in a Tertiary Hospital in North-Central Nigeria. J Med Tropics. 2011; 13 (2): 95-97.

[9] Ogunlesi T, Fetuga B, Olowonyo M, Adekoya A, Adetola O, Ajetunmobi A. Severe Childhood Anaemia and Blood Transfusion in a Nigerian Secondary Level Facility. $J$ Trop Pediatrics. 2016; 62, 107-115.

[10] Akech S, Maitland K. Changing trends in blood transfusion in children and neonates admitted in Kilifi District Hospital, Kenya. Malar J. 2010; 9: 307. https://doi.org/10.1186/14752875-9-30710.

[11] Goncalez TT, Sabino EC, Capuani L, Liu J, Wright DJ, Walsh $\mathrm{JH}$ et al. Blood transfusion utilization and recipient survival at Hospital das Clinicas in São Paulo, Brazil. Transfusion. 2012 Apr; 52 (4): 729-738.

[12] Shari C R, Sawe H R, Murray B L, Victor M G, Mfinanga J A, Runyon M S. Emergency blood transfusion practices among anaemic children presenting to an urban emergency department of a tertiary hospital in Tanzania. BMC Hematol. 2017; 17: 19 .

[13] Schumacher RF, Spinelli E. Malaria in children. Mediterr $J$ Hematol Infect Dis. 2012; 4 (1): e2012073. doi: 10.4084/MJHID.2012.073.

[14] Malnutrition-Fact sheet WHO. https://www.who.int/newsroom/fact-sheets/detail/malnutrition [Accessed $20^{\text {th }}$ September 2020].
[15] Takele K, Zewotir T, Ndanguza D. Risk factors of morbidity among children under age five in Ethiopia. Am J Trop Med Hyg. 2016; 94 (3): 691-694. doi: 10.4269/ajtmh.15-0310.

[16] Ilechie O A, Combey T, Onyeabor O S, Okorie C, Sanyaolu A O. Evaluation of Blood Transfusions in Anemic Children in Effia Nkwanta Regional Hospital, Sekondi-Takoradi, Ghana. BMC Public Health. 2019; 19: 942.

[17] Malaria-Fact sheet WHO. https://www.who.int/newsroom/fact-sheets/detail/malaria [Accessed 20 ${ }^{\text {th }}$ September 2020].

[18] Samd L M, Ajayi J A, Oguche S. Seasonal Variation of Malaria Parasite Density in Paediatric Population of North Eastern Nigeria Glob J Health Sci. 2012 Mar; 4 (2): 103-109.

[19] Okwa OO. Nipping the Malaria Vectors in the Bud: Focus on Nigeria.

DOI: $10.5772 /$ intechopen.83554January $28^{\text {th }} 2019 /$ malaria/nippingthe-malaria-vectors-in-the-bud-focus-on-n2.

[20] Mattah PAD, Futagbi G, Amekudzi LK, Mattah MM, Souza DK, Kartey-attipoe WD, et al. Diversity in breeding sites and distribution of Anopheles mosquitoes in selected urban areas of southern Ghana. Parasit Vectors. 2017; 10 (1): 25.

[21] Olutola A, Mokuolu OA (February $29^{\text {th }} 2012$ ). Severe Malaria Anaemia in Children, Anemia, Donald S. Silverberg, Intech Open, $\quad$ DOI: $\quad 10.5772 / 28616$ https://www.intechopen.com/books/anemia/seere-malariaanaemia-in-children.

[22] Nanvya N, Mulambalah C, Ajiji J, Nanvya DADN, Mulambalah C, Ajiji J. Prevalence of Human Malaria Infection and its Transmission Pattern in the Highlands and Lowlands of Plateau State, Nigeria. Indian Journal of Science and Technology. 2017; 10 (32): 1-9.

[23] Jiya NM, Yusuf T, Airede KI. Severe anaemia in childhood in Sokoto, Nigeria. Sahel medical journal. 2006; 9 (2): 52-55.

[24] Al-Riyami A Z, Daar S. Transfusion in Haemoglobinopathies. Review and recommendations for local blood banks and transfusion services in Oman. Orphanet $J$ Rare Dis. 2013; 8: 143.

[25] Thomas J, Ayieko P, Ogero M, Gachau S, Nyachiro M W, Mbevi G, et al. Blood Transfusion Delay and Outcome in Countys Hospitals in Kenya. Am J Trop Med Hyg. 2017; 96 (2): 511-517.

[26] Abhulimhen-Iyoha BI, Israel-Aina YT. Emergency Blood Transfusion in Children in a Tertiary Hospital in Nigeria: Indications, Frequency and Outcome. West Afr J Med 2018; 35: $20-24$. 